ISSN: 2716-1277

e-ISSN: 2716-1269 TIC https://jlic.iain-jember.ac.id/
Journal of Language Intelligence and Culture

Fakultas Tarbiyah dan Ilmu Keguruan

IAIN Jember

Vol. 3, No.2, Page 139-156, December 2021

\title{
Teachers' Strategy to Develop Higher Order Thinking Skills in Reading Class
}

\author{
Yesi Elsa Fitriani, \\ Universitas Majalengka \\ Email: yesifitrianiyanuar@gmail.com \\ Eva Fitriani Syarifah, \\ Universitas Majalengka \\ Email: evafitrianisyarifah@unma.ac.id \\ Raynesa Noor Emiliasari, \\ Universitas Majalengka \\ Email: raynesanoor@gmail.com
}

\section{ARTICLE INFO \\ Article History: \\ Accepted: September 2021 \\ Approved: December 2021 \\ Published: December 2021 \\ Key Words: \\ Teaching strategy, higher order thinking skills, reading class}

DOI: $10.35719 / j$ lic.v3i2.59

\begin{abstract}
This research aims to find out the strategies used by the teachers and the inhibiting factors that can influence the development of HOTS in Reading Class. It applied qualitative approach with case study research design. The subject of the research were two English teachers of Senior High School. The techniques of collecting the data were used observation and interview. The data were analyzed using the qualitative method there are data reduction, data display, and drawing conclusions. The finding of the research shows that there were 5 types of teaching strategies, including informing learning objectives, divergent questions, group discussion, giving feedback and giving motivation. The most dominant strategy used by the teacher was divergent question. Meanwhile, the learning objective and group discussion was the least prominent, with only 3 data. Then, five inhibiting process such as time, pupil learning ability, pupil's mastery, planning domain, and class environment can influence the development of HOTS.
\end{abstract}

\section{INTRODUCTION}

Education is one of the significant aspects to influence the national vision. Success in implementing education is the key to a better future. It requires the contribution of many parties, one of which is the teacher. "The role of teachers is hugely influential because they put all education policies and regulations into practice" 


\section{JLIC}

(Retnawati et al., 2018:215). The spearhead of the success of education in school is the teacher. Therefore, a teacher expects to be an innovative person to find effective strategies or methods to educate students. Wright (1987) stated that "the dominant key the teacher must hold is that any innovative process or product that is carried out and produced by teacher must refer to the interests of students".

The efforts to improve the quality of education cannot be separated from the demands of 21st-century competitiveness, which is complex and challenging. The 21st century learning system is a learning transition where the currently developed curriculum requires educational institutions to change a teacher-centered learning approach to a student-centered learning approach. In simple terms, it can be defined as learning that provides 2ist century skills to students, namely ${ }_{4} \mathrm{C}$ which includes: (1) Communication (2) Collaboration, (3) Critical Thinking and problem solving, and (4) Creative and Innovative. English teachers are required to use HOTS during the teaching process. Since the 2013 Curriculum, English teachers have been encouraging to use HOTS by involving students during the learning process which encourages activities beyond comprehension. These activities should encourage analysis, synthesis and evaluation.

Higher-order thinking skills (HOTS) are one of the critical components for an individual to solve a new problem in the 21st century (Brookhart, 2010:8). According to Thomas \& Thorne (2009), HOTS plays a crucial role in applying, connecting, or manipulating the prior knowledge to solve recent problems. Anderson \& Krathwohl (2001), in the revised Bloom's taxonomy, defined HOTS as an incision among the three top levels of ability in the cognitive dimension (analyzing, evaluating, \& creating). Therefore, HOTS is measured using tasks, including analyzing, evaluating, and creating conceptual \& procedural knowledge. It is very necessary to familiarize student with HOTS activities because it can help students prepare to solve recent problems, adjust to new situations, and decide about specific problems, especially in the fast progress of the 21st century.

Currently, "reading ability becomes the most important language skill for English as a Foreign Language (EFL) or second language (ESL) students in academic contexts" (Grabe, 2010). As shown below, reading comprehension, growth of fluency, and enjoyment in reading should go hand in hand and must be built up 
together over time through training. According to Nuary (2015), "the cultivation of good readability can involve extensive struggle for many students in EFL context, particularly for those who are still at the low level of understanding". This condition can substantially contribute to a lack of enjoyment and less learning that will engender lower understanding and fluency. "This precisely explains why a growing number of teachers and researchers have paid attention to the extensive reading program, especially since the 1990s" (Grabe, 2010). Day and Bamford (2002) suggest that "the first successful experience of the students in extensive reading leads to a finding, which is enjoyable and rewarding in the second language". "This stimulates the development of positive reading approaches, which are reinforced in subsequent extensive readings" (Day \& Bamford, 2002, p. 30).

The relationship between reading skills and critical thinking has been highlighted by cognitive psychology. Critical thinking can be taken as a means by which schema can be activated or created. According to Aloqaili (2012), "the schema has an interactive relationship with reading comprehension between the prior knowledge of readers and the read text". Readers sometimes come to a different understanding based on their experience. As Aloqaili (2012) argues, "having reading as a critical thinking act becomes more manageable if some of the readings are recognized as automatic and essential, but not enough to develop an understanding of the text". The introduction of HOTS to tackle reading problems can facilitate students to develop their understanding of texts.

There are five strategies for developing reading using Higher Order Thinking Skills, according to research conducted by Marina et al. (2015). Those are asking a divergent question, informing learning aim, group discussion, giving feedback, and giving motivation. Teachers can present interesting readings based on students' interests and language skills so as to prepare students to read and develop their thinking by showing interesting visual aids related to the topic, making predictive models, asking questions, and encouraging their discussion. Based on the 2013 curriculum, a teacher must be able to develop students' Higher Order Thinking Skills.

There are some relevant studies related to the teacher strategy to develop HOTS in teaching reading skills. Samelian (2017) entitled "How Higher Order Questioning and Critical Thinking Affects 


\section{JLIC}

Reading Comprehension". Conducted a classroom action research (CAR) to investigate how she can improve fifth-graders' reading comprehension using critical thinking and higher-order questioning research. The results showed that higher-order questioning and critical thinking can improve understanding of critical thinking skills and help students engage in high-level thinking to strengthen their reading comprehension. Pasutri (2020) entitled "Teachers' Strategy and Challenges in Teaching Higher-Order Thinking Skills in the Rural Area: A Case Study At Junior High School In Gaung District, Inhil, Riau". This research uses a qualitative approach by observing as observers in the teaching and learning process, conducting interviews with English teachers, and collecting lesson plans made by English teachers in one of the junior high schools in Gaung District. The result of this research showed that the teacher used determining learning objectives with the eight characteristics of the lesson plan for the 2013 curriculum. Suryani (2019) entitled “Teacher's Strategies in Teaching Reading to Students' Eight Grade at Madrasah Tsanawiyah Tarbiyatus Sholihin Muaro Jambi". This research was conducted through observation and interviews to collect data. The results showed that teacher's strategy in teaching reading comprehension in the eighth grade of Madrasah Tsanawiyah Tarbiyatus Sholihin Muaro Jambi use working in small groups. While Maulidina (2020) entitled 'Teacher's Strategies to Enhance Students' Higher Order Thinking Skills in Teaching Reading to The Seventh Grade Students of SMP Al-Islam 1 Surakarta. The research used descriptive qualitative research. The result showed that strategy to develop HOTS in reading comprehension are giving feedback and motivation.

Based on the explanation of the problem that has been described, the researcher is interested in knowing the teachers' strategy of using HOTS, especially in reading comprehension in the hope that later it can encourage students to use their knowledge and find ways to solve these problems. In accordance with the previous studies and context, this study proposes the title "Teachers' Strategy to Develop Higher Order Thinking Skills in Reading Comprehension". 


\section{METHODS}

The researcher used a qualitative approach type case study because it focuses on a single unit such as an individual, group, organization, or program (Cresswell: 2012, Ary, Jacobs, and Sorensen: 2010). The researcher applies a set of procedures used for problem solving based on factual data where the researcher is the key instrument, sampling is done with purposive data, collection techniques are triangulation, data analysis is inductive or qualitative with results that emphasize meaning and purpose rather than generalization.

The subjects of this research were two English teachers in senior high schools. This study uses triangulation because it can strengthen evidence or findings through different individuals (Emzir, 2010). There are three types of qualitative data analysis activities, among them data reduction, data display, conclusion or verifying (Miles and Huberman, 2013: 8).

\section{RESULTS AND DISCUSSION}

Applying HOTS in the reading comprehension learning process is very necessary. Teachers must have several strategies in learning reading comprehension, especially when teachers apply HOTS. This section presents the results of research data obtained by researchers from observations and interviews. This study aims to determine the strategies used by teachers to develop HOTS in reading comprehension. The result of the observations can be seen below.

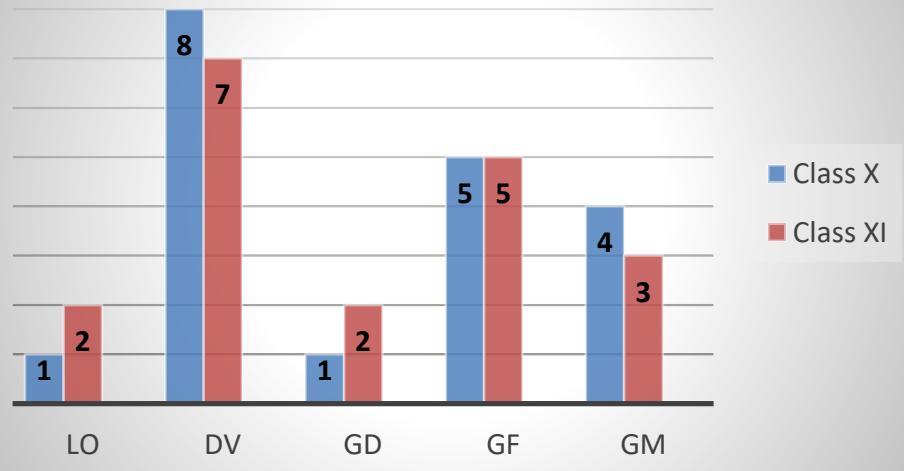

Figure 1. Teachers' Strategies to Develop HOTS in Reading Comprehension 


\section{JLIC}

Note: LO (Learning Objectives), DQ (Divergent Questions), GD (Group Discussion), GF (Giving Feedback), and GM (Giving Motivation)

In this section, the researcher analyzes the teacher's strategy to develop HOTS in reading comprehension. The teacher plans strategies to teach students in the classroom, especially in teaching and learning reading comprehension. Based on the diagram above, the teacher uses several steps in teaching reading comprehension, such as learning objectives, divergent questions, group discussion, giving feedback, and giving motivation.

\section{Learning Objectives}

From the above observations, teacher A informs the learning material, namely historical events: Spanish flu in recount text, while teacher B explains the material asking and giving opinion through video and then holds a quiz sessions. One of the observation data showed below:

Teacher A : In the last week we learn about biography, now Miss will review the historical event: spanish flu, especially for your understanding in the text recount reading comprehension.

Teacher B : Today's we learn about asking giving opinion. Please watch this video in sequence, after that we will discuss. Tune in until 10.35. After that, come back to this forum because there will be a quiz!

The statement above is also strengthened by interviews conducted with teachers about learning objectives. The two teachers explained further:

Researcher : Before starting the lesson, did you explain the learning objectives first?

Teacher A : Sometimes yes, sometimes I forget....hahaha.... Teacher B : Yes.

Based on the results of the observations and interviews above, it can be concluded that before starting the lesson the teacher explains the learning objectives first to the students. Teachers use this strategy to apply HOTS in teaching reading skills to develop critical thinking so that students can start brainstorming, analyzing, and creating. The purpose of informing the learning objectives is that students can appreciate the techniques used by the teacher. This findings are in line with the theory of Limbach \& Waugh (2010:3) 
about teachers who inform learning objectives from the beginning of the learning process to help improve students' critical thinking skills.

\section{Divergent Questions}

Divergent questions are types of questions about finding the right answer by making students analyze, evaluate, and create. The two teachers use questions to review, examine learning, and challenge students to think critically. These questions can improve students' skills in analyzing recount texts and asking giving opinion materials delivered by the teacher.

a. Analyzing

In analyzing the recount text and asking giving opinion, teacher A invites students to analyze the generic structure in the text, while teacher $\mathrm{B}$ invites students to analyze the generic structure in the sentence. It can be seen in the teaching and learning process as follows:

Teacher A : Well students, according to the text above, please identify about generic structures. For example orientation lies on paragraph 1. Look this!

Teacher B : Okay, let's go to the quick quiz... per question, Miss, I'll give you 5 minutes to answer!!! “Dian, what do you think about science?" Well, do you think this is included in asking opinion or giving opinion? What are the characteristics? With a personal or general point of view?

b. Evaluating

After that, teacher A asked students to imagine using sentence structures such as If I become...., I will..... while teacher B asked students to express opinions in the text. These activities can evaluating students' understanding of the recount text material and asking giving opinion. It can be seen in the teaching and learning process as follows:

Teacher A : Please say something, about your imagination. So the sentence structure kind of like: If I become...., I will..... It is not so hard, isn't it?

Teacher B : (Teacher send a text) How do you think about this? Please state your opinion in English!

c. Creating 


\section{JLIC}

Then, teacher A asked students to make a recount text video in the form of historical events, while teacher B asked students to make an opinion about the text. It can be seen in the teaching and learning process as follows:

Teacher A : For the last assignment, you should make and compile recount video about historical, 1:30 minutes. The deadline will be informed later. Make sure you prepare your own text.

Teacher B : Okay, for the assignment, please give your own opinion about the article, I will send the link later on google classroom.

The statement above is also strengthened by interviews conducted with teachers about teach through divergent questions. The two teachers explained further:

Researcher : Do you teach by asking students questions?

Teacher A : Of course, that question is very important, yes, and the question is eee... not where... what... what... how much... don't be like that, yes, but the question is more about how... why... why... why... so that's it, so the questions... that provokes them to think, to think analytically.

Teacher B : Yes.

Based on the findings from the observations and interview above, teacher A invites students to analyze the generic structure in the text, asks students to imagine using sentence structures such as If I..., I will..., and asks students to make recount text videos in the form of historical events. Meanwhile, teacher B invites students to analyze the generic structure in sentences, asks students to express opinions in the text, and asks students to make opinions about the text. So it can be concluded that the two teachers teach by asking students questions but the type of question must provoke students to think critically and analytically. Samelian (2017) states that HOTS could improve students' understanding of critical thinking skills and help them engage in high-level thinking to strengthen their understanding of reading comprehension skills. Likewise, Samelian's (2017) findings and these research findings also show the same kind of similarities. Samelian (2017) uses the storybook but the current study applied recount text and the sentence asking giving opinion. The findings are in line with the theory of Limbach \& Waugh (2010) 
who state that teaching through question could develop students' critical thinking.

\section{Group Discussion}

Teacher A asks students to make groups of ten people. Then teacher A gives the recount text to students to read and analyze its generic structure with his friends. If students complete their assignments, teacher A asks students to submit their assignments after learning and directs students to make presentations in front of the class. Meanwhile, Teacher B divides the students into groups. Then Teacher B asks the students to read the text that has been prepared after which it is analyzed which includes asking and giving opinion. If students complete their assignments, teacher B asks students to submit their assignments after learning and directs students to make presentations in front of the class. It can be seen in the teaching and learning process as follows:

Teacher A : Okay that's enough. Next, I have created a group of 10 people. Please see your names. (Teacher sent the text) Your task is to read this text, then determine the generic structure, OK? Discuss with your group mates.

Student : (After doing the assignment).

Teacher A :The presentation will be next week, yes, what was sent here earlier, I will determine who will present it.

Student : Yes miss.

In this statement, the two teachers using group discussion sessions. This is also strengthened by interviews conducted with teachers about using group discussions. The two teachers explained further:

Researcher : Do you ask students to discuss with their friends in learning?

Teacher A : Of course, of course yes. The child must be able to communicate, discuss with his friends.

Teacher B : Yes, of course.

Based on the findings from the observations and interviews above, it can be concluded that after the students understood the teacher's explanation, the two teachers asked the students to analyze a text. Meanwhile, after completing the task, students must present their work in front of the class. However, due to insufficient time, both teachers decided that students should submit their work first and would make a presentation at the next meeting. It can be seen 


\section{JLIC}

from the dialogue above, that the two teachers used discussions to train students to carry out text analysis procedures with their peers. This findings are in line with the theory of Samelian (2017), who also used discussion strategy where students had discussions with peers. Besides, according to Burt \& Adams, 2003; Van Duzer, 1999), group discussion will further develop students' thinking by exchanging ideas and giving opinions to each other new things students receive in classroom. Group discussions by teacher to students or students with students can improve students to take part more actively, have more confidence, and increase their motivation to take reading class (Siswanti et al., 2012).

\section{Giving Feedback}

Provide feedback aims to invite students to start reviewing, refining and improving understanding of the material that has learned. Before the lesson is over, the two teachers asked the students to review, refine, and improve understanding regarding the material learned that day.

a. Review

One of the most powerful ways to find out if learning is like what the teacher expected is to include time to review what has learned. Reviews make it easier for students to consider information and accelerate students to store memories in their brains. This strategy challenges students to recall each lesson subject that has been studied. It could be seen observation below:

Teacher A : Well, after you learned about the recount text, what did you get from lesson today? Please your answer, guys...!!!

Student : After studying recount text I learned what is recount text and what are the structure generic of recount text.

Teacher A : That's right. Today we have learned about recount text and generic structure.

Teacher B : Students, what did we learn?

Student : Asking and giving opinion, characteristics, same point of view, miss.

Teacher B :Yes, that's right.

b. Refine 
Refine helps students to broaden the understanding of a concept and deepen it. It also helps to apply thinking skills and application of knowledge. It could be seen observation below:

Teacher A : Today we have studied recount text, what is recount text? Anyone still remember or not?

Student : Still miss. Recount text is a text which retells events or experiences in the past. Its purpose is either to inform or to entertain the readers.

Teacher A : About what?

Student : Hortatory events.

Teacher A : That's good.

Teacher B : The children still remember how to tell the difference between formal and informal asking, ok?

Student : In formal use standard language while informal use non-standard language.

Teacher B : Yupz. That's good. What is the style of language like?

Student : If it's formal, the language style is long and polite, if it's informal, it's shorter and relaxed, miss.

Teacher B : Right.

c. Improve understanding

Improving understanding helps students develop metacognitive skills that aim to improve students' skills in critiquing material by ensuring students understand the material to the fullest. It could be seen observations below:

Teacher A : Anyone know about recount text? What type of hortatory?

Student : Hortatory events about Spanish flu, miss.

Teacher A : Yes, that's right. We studied Hortatory events about the Spanish flu, yes, you were asked to identify the generic structure of the text in which paragraph. So far, you understand what it means, right?

Student : Yes, miss.

Teacher B : What have you learned today about asking and giving opinion? Anyone know?

Student : The characteristics are the same as point of view. 


\section{JLIC}

Teacher B : That's right. You are asked to analyze which sentence includes asking and which includes giving, the characteristics as well, what is the point of view and you were asked to listen to the video as well and then express your opinion. You are understand?

Student : Yes, miss.

The above statement was also strengthened by interviews conducted with two teachers about giving feedback. The two teachers explained further:

Researcher : Do you give feedback to students after the teaching and learning process?

Teacher A : Yes... if it is deemed necessary, especially if for example a student presents an answer, we will give the positive and the negative, even if it is only one... two... sentences.

Teacher B : Yes.

Based on the results of the observations and interviews above, it can be concluded that the two teachers provide feedback to students and invite students to review, refine, and improve understanding before learning is complete. Both teachers review the material with students so that students become more active. After reviewing the material, the two teachers developed the material with the students. It aims to help students to improve their criticizing skills by ensuring that students have fully understood the material. Then, the two teachers assessed the students during the review, improvement, and improvement stages. All these things are done to find out whether students really understand the material or not. This is also done to determine the students' abilities about how successful the strategy is for students. This findings are in line with the theory of Limbach \& Waugh (2010: 6) to examine, refine, improve understanding, train feedback, and assess critical thinking learning. Teachers should provide students with useful feedback through frequent opportunities to practice whatever the teacher expects students to do at the time of assessment.

\section{Giving Motivation}

Motivation can be used to make students always focus when studying. In connection with this, the teacher always motivates 
students when teaching in class. This can be seen from the obseravtions below:

Teacher A : Well students, according to the text above, please identify about generic structures. For example orientation lies on paragraph 1. Look this! Those who answer get points yes.

Student : Along the human history, there were some pandemic had ever hit people all over the word.

Teacher A : Nice work. Yeeeee (Applause).

Teacher B : Next question!!! "I think science is fun but it's a bit complicated." Included in asking opinion or giving opinion? I'll give you points.

Student : Included in giving opinion. Miss.

Teacher B : Good job students (Thumbs up).

The above statement was also strengthened by interviews conducted with two teachers about giving motivation. The two teachers explained further:

Researcher : What motivation do you give to students in learning reading?

Teacher A : The students will feel appreciated for his work if we give motivation, for example the students does something in writing with us giving additional points or points, yes, that is also motivation and the students will be happy if the results of his work are appreciated. We give a thumbs up, the children are not happy, we give applause, we give stickers that motivate them, they will be happy and they will be actively involved in learning.

Teacher B : Of course, after asking the students, motivate the students and appreciate the students so that the children feel happy, happy, and enjoy. For example, if we ask a question, try mentioning this, so the one who can answer will give you additional points. Well, things like that are included in motivating students, eeee.... There's more, right, in WA groups, there are stickers, yes, I like to use that too.

Based on the results of the observations and interviews above, the two teachers motivated the students by giving additional points and giving motivational stickers such as clapping and raising their 


\section{JLIC}

thumbs. According to Bhushan (2014:11), motivation is the main important factor that stimulates critical thinking and creativity. The teacher motivated students to think critically by asking questions about the material that has been studied. If the students can answer correctly, they will get praise and additional points. Sometimes even the teacher will gave other prizes that can be used by students to study. This findings are in line with theory of Hung et al (2011) which stated that critical thinking can empower students to be motivated to learn more persistently when faced with a task. Therefore, providing challenges can motivate students to learn how to get more involved. With this strategy, it can foster critical thinking in students when learning how to read.

\section{CONCLUSION}

From the explanation above it can be concluded that: (1) teachers used five strategies to develop HOTS. The strategies are; informing the learning objectives, giving divergent questions; implementing group discussion, giving feedback, and giving motivation. Among the five strategies, the most dominant divergent questions used by teachers were 15 of 38 data. Followed by giving feedback with 10 data, giving motivation with 7 data, learning objectives with 3 data, and group discussion with 3 data. The five strategies carried out by two teachers in one of the senior high school is aimed at developing HOTS in English Class. (2) there are five factors, from the inhibiting factors, that can influence the development of HOTS in reading comprehension. Among other things (1) time; (2) pupil learning ability; (3) pupil's mastery; (4) planning domain; and (5) classroom environment.

\section{REFERENCES}

Aloqaili, A. S. (2012). The relationship between reading comprehension and critical thinking: A theoretical study. Journal of King Saud University - Languages and Translation, 24(1), 35-41. https://doi.org/10.1016/j.jksult.2011.01.001

Anderson, L.W., Krathwohl, D.R. (2001). A Taxonomy of Learning, Teaching, and Assessing: A Revision of Bloom's Taxonomy of Educational Objectives. New York: Longman 
Ary, Donald., Jacobs, L. C., \& Sorensen, Christine. (2010). Introduction to Research in Education. Canada: Wadsworth Cengage Learning.

Bhushan, R. (2014). Developing Learner's Critical Thinking and Motivation. International Journal on Studies in English Language and Literature (IJSELL), 2(6), 11-16. Retrieved from www.arcjournals.org

Brookhart, S. M. (2010). How to assess higher-order thinking skills in your classroom. Alexandria, Virginia: ASCD. Retrieved from www.ascd.org

Burt, M., Peyton, J. K., Linguistics, A., States U., \& Adams, R. J. (2003). Reading and Adult English Language Learners: A Review of the Research. Washington, DC: Center for Applied Linguistics.

Cresswell, John W. (2012). Educational Research. University of Nebraska, Lincoln.

Day, R., \& Bamford, J. (2002). Top Ten Principles for Teaching Extensive Reading. Reading in a Foreign Language, 14(2), 136.

Emzir. (2010). Metode Penelitian Kualitatif: Analisis Data. Jakarta:Rajawali Pres.

Grabe, W. (2010). Fluency in Reading - Thirty-Five Years Later. Reading in a Foreign Language, 22(1), 71-83.

Hung, S. Durciknova, A., Lai, H., \& Lin, W. (2011). The Influence of Intrinsic and Extrinsic Motivation on Individuals' Knowledge Sharing Behavior. Journal of Human Computer Studies, 69(6), 415-427. Retrieved from https://doi.org/10.1016/j.ijhcs.2011.02.004.

Limbach, B., \& Waugh, W. (2010). Developing Higher Level Thinking. Journal of Instructional Pedagogies, 9. Retrieved February 2018 from https://aabri.com/manuscripts/o9423.pdf

Marina, L., Acosta, E., \& Ferri, M. M. (2015). Reading strategies to develop higher thinking skills for reading comprehension. Profile Issues in Teachers Professional Development, 12(1), 107123.

Maulidina, H. (2020). Teacher's Strategies to Enhance Students' Higher Order Thinking Skills in Teaching Reading to The Seventh Grade Students of SMP Al-Islam 1 Surakarta. Unpublished Thesis. English Language Education Cultures and language Faculty The State Islamic Institute of Surakarta. 
Miles, M.B. \& Huberman, M.A. (2014). Qualitative Data Analysis: A Methods Sourcesbooks 3th Ed. Thousand Oaks: SAGE Publications Inc.

Nuary, C. (2015). The Implementation of Discussion in Teaching Reading at Seventh Grade of SMP Murni 1 Surakarta. Unpublished Thesis. English Language Education Cultures and language Faculty Muhammadiyah Surakarta University.

Pasutri, N.S. (2020). Teachers' Strategy And Challenges In Teaching Higher-Order Thinking Skills In The Rural Area: A Case Study At Junior High School In Gaung District, Inhil, Riau. Unpublished Thesis. English Language Education Cultures and language Faculty Muhammadiyah Surakarta University.

Retnawati, Heri et al. (2018). Teachers Knowledge about Higher Order Thinking Skills and its Learning Strategy. Problem in Education in the 21th Century; vol. 76 no. 2.

Samelian, L. A. (2017). How Higher Order Questioning and Critical Thinking Affects Reading Comprehension (Hamline University). Retrieved from http://digitalcommons.hamline.edu/hse_all

Siswanti, F., \& Setyaningsih, N. (2012). The Use of Small-Group Discussion to Improve Students' Reading Comprehension. English Education, 2(2), 216- 232.

Suryani, W. (2019). Teacher's Strategies in Teaching Reading to Students' Eight Grade at Madrasah Tsanawiyah Tarbiyatus Sholihin Muaro Jambi. Unpublished Thesis. English Education Department. Education Faculty and Teacher Training The State Islamic University Sulthan Thaha Saifudin Jambi.

Thomas, A., and Thorne, G., (2009). How to Increase Higher Order Thinking. Metarie, LA: Center for Development and Learning. Retrieved Sept. 10, 2020, from http://www.cdl.org/resourcelibrary/articles/HOT.php?type= subject\&id $=18$.

Wright, Lesley. (1987). Physical Education and Moral Development. Journal of Philosophy of Education, 2(1). Retrieved from https://doi.org/10.1111/j.1467-9752.1987.tboo146.x. 